\title{
A study on the fine structure of marine diatoms in Korean coastal waters: Genus Thalassiosira 5
}

\author{
Joon Sang Park ${ }^{1}$ and Jin Hwan Lee ${ }^{1, *}$ \\ ${ }^{1}$ Department of Biology, Sangmyung University, Seoul 110-743, Korea
}

\begin{abstract}
Thalassiosira species were collected from October 2007 to January 2009 in an attempt to better understand species diversity of the genus Thalassiosira in Korean coastal waters. A total of 5 Thalassiosira species (T. concaviuscula, T. oceanica, T. partheneia, T. simonsenii and T. nanolineata) were identified here. Most species in this study were of small size, and 5 species were recorded for the first time in Korean coastal waters. Using a scanning electron microscope (SEM), we described distinctive characteristics of fine structure that proved to be important diagnostic characteristics for the identification of each species. The most important diagnostic characteristics for Thalassiosira species identification were the marginal strutted processes, the position of labiate processes, and the areolation. The differential characteristics of the species studied were: T. concaviuscula has a double layered external tubes on the marginal strutted processes; T. oceanica shows marginal ridges that are interlinked between the marginal strutted processes; the valve face of T. partheneia is fairly convex and its labiate process is positioned midway between two strutted processes; T. simonsenii is characterized by two labiate processes and somewhat coarse areolae; and, T. nanolineata has several central strutted processes and linear areolation.
\end{abstract}

Key Words: Bacillariophyceae; fine structure; light microscope; scanning electron microscope; Thalassiosira

\section{INTRODUCTION}

The diatom genus Thalassiosira comprises more than 100 species (Hasle and Syvertsen 1996). Biodiversity assessments in the genus Thalassiosira are particularly important for understanding the different ecological roles played by each species (Harris et al. 1995, Hoppenrath et al. 2007). The structure of strutted and labiate processes, the areolation pattern, and the structure of girdle band are the most striking characteristics for identification of Thalassiosira species (Hasle 1968, 1978, Hasle and Fryxell 1977, Fryxell et al. 1981, Makarova 1988, Hasle and Syvertsen 1996). Fine structures in most Thalassiosira species are difficult to recognize using light microscopy (LM) alone. Therefore, scanning electron microscopy (SEM) examination of the frustules has been considered the most suitable means for species identification.

In Korean coastal waters, studies have been carried out to confirm the real number and identification of Thalassiosira species present (Lee and Yoo 1986, 1987, Lee and Park 2008, Park et al. 2009). Park et al. (2009) recorded thirty-one species of Thalassiosira from Korean coastal waters. They suggested that further detailed taxonomic investigations are needed to reveal the accurate number of Thalassiosira species present in Korean waters.

This study was conducted in a series providing the (c) This is an Open Access article distributed under the terms of the Creative Commons Attribution Non-Commercial License (http://creativecommons.org/licenses/by-nc/3.0/) which permits unrestricted non-commercial use, distribution, and reproduction in any medium, provided the original work is properly cited.
Received 18 May 2010, Accepted 9 August 2010

"Corresponding Author

E-mail: jhlee@smu.ac.kr

Tel: +82-2-2287-5152, Fax: +82-2-2287-0098 
fine structure, description, distribution and taxonomic remarks of 5 Thalassiosira species in Korean coastal waters. In addition to the species discussed in this paper, we include a list of species previously reported, but not studied in detail, from Korean coastal waters.

\section{MATERIALS AND METHODS}

Sample collections were executed from October 2007 to January 2009 in Korean coastal waters (Table 1). Phytoplanktons were collected using a $20 \mu \mathrm{m}$ mesh net by vertical towing. Samples were immediately fixed with neutralized formalin (5\% final concentration). Using a method presented by Hasle and Fryxell (1970), organic matter in the diatom cells was removed. Prepared diatom material was observed under a light microscope (Axioskop 40; Carl Zeiss Jena, Jena, Germany) and a scanning electron microscope (JSM-5600LV; Jeol, Tokyo, Japan), and photographed with an MRc5 camera (Carl Zeiss Jena). Diatom size analysis was completed with image calculation software (AxioVision AC version 4.5; Carl Zeiss Jena). Terminology was adopted from the Working Party on Diatom Terminology (Anonymous 1975).

\section{RESULTS AND DISCUSSION}

This study adopted Simonsen's (1979) natural system of diatoms, summarized as follows:

Class Bacillariophyceae Haeckel 1878

Order Centrales Hustedt 1930
Suborder Coscinodiscineae Simonsen 1979

Family Thalassiosiraceae Lebour 1930, emend. Hasle 1973 Genus Thalassiosira Cleve 1873

Thalassiosira concaviuscula Makarova 1978

T. nanolineata (Mann) Fryxell and Hasle 1977

T. oceanica Hasle 1983

T. partheneia Schrader 1972

T. simonsenii Hasle and Fryxell 1979

Table 2 summarizes morphological characteristics of the 5 Thalassiosira species studied here. The 5 Thalassiosira species are discussed in alphabetical order. Each description includes literature references used for identification and results from LM and SEM.

\section{Thalassiosira concaviuscula Makarova (PI. 1, figs 1-8)}

Makarova 1978, p. 222, Pl. 1, figs 1-11; Harris et al. 1995, p. 120, Figs 5 \& 23; Hoppenrath et al. 2007, p. 274, Figs 8-10.

Cells are 6.4-20.4 $\mu \mathrm{m}$ in diameter. Valves have fine areolae arranged in sectors, with $40-45$ areolae per $10 \mu \mathrm{m}$. One central strutted process is adjacent to a large areola and one marginal ring of strutted processes with relatively short external tubes. There are four to eight marginal processes per $10 \mu \mathrm{m}$. One labiate process is displaced inside the marginal ring of strutted processes. Valves are flat in the girdle view. In the external view, one central strutted process has a short tube, while the marginal strutted processes have double layers with an external flared skirt. The labiate process has a simple tube without an external flared skirt. In the internal view, all strutted processes have 4 satellite pores. The labiate process is tangentially sessile.

Table 1. Thalassiosira spp. collection data in coastal waters of Korea

\begin{tabular}{|c|c|c|c|c|}
\hline Species & Sampling date & Sampling location & Longitude & Latitude \\
\hline \multirow[t]{4}{*}{ Thalassiosira concaviuscula Makarova } & Dec. 6, 2007 & Jinhae Bay & $128^{\circ} 42^{\prime} 13^{\prime \prime} \mathrm{E}$ & $35^{\circ} 06^{\prime} 15^{\prime \prime} \mathrm{N}$ \\
\hline & Jan. 23, 2009 & Naksan Harbor & $128^{\circ} 37^{\prime} 57^{\prime \prime} \mathrm{E}$ & $38^{\circ} 07^{\prime} 24^{\prime \prime} \mathrm{N}$ \\
\hline & Jan. 23, 2009 & Geojin Harbor & $128^{\circ} 27^{\prime} 47^{\prime \prime} \mathrm{E}$ & $38^{\circ} 26^{\prime} 50^{\prime \prime} \mathrm{N}$ \\
\hline & Sep. 28, 2007 & Ulsan Bay & $129^{\circ} 23^{\prime} 45^{\prime \prime} \mathrm{E}$ & $35^{\circ} 06^{\prime} 15^{\prime \prime} \mathrm{N}$ \\
\hline \multirow{2}{*}{$\begin{array}{l}\text { T. nanolineata } \\
\text { (Mann) Fryxell and Hasle }\end{array}$} & Dec. 27, 2008 & Mokpo Gwansado & $125^{\circ} 58^{\prime} 47^{\prime \prime} \mathrm{E}$ & $34^{\circ} 18^{\prime} 26^{\prime \prime} \mathrm{N}$ \\
\hline & Dec. 27, 2008 & Mokpo Nurokdo & $125^{\circ} 57^{\prime} 34^{\prime \prime} \mathrm{E}$ & $34^{\circ} 20^{\prime} 52^{\prime \prime} \mathrm{N}$ \\
\hline T. oceanica Hasle & Oct. 22,2007 & Incheon coast & $126^{\circ} 32^{\prime} 49^{\prime \prime} \mathrm{E}$ & $37^{\circ} 22^{\prime} 46^{\prime \prime} \mathrm{N}$ \\
\hline T. partheneia Schrader & Oct. 22,2007 & Incheon coast & $126^{\circ} 32^{\prime} 49^{\prime \prime} \mathrm{E}$ & $37^{\circ} 22^{\prime} 46^{\prime \prime} \mathrm{N}$ \\
\hline \multirow{3}{*}{$\begin{array}{l}\text { T. simonsenii } \\
\text { Hasle and Fryxell }\end{array}$} & Dec. 27, 2008 & Mokpo Jujido & $126^{\circ} 05^{\prime} 10^{\prime \prime} \mathrm{E}$ & $37^{\circ} 29^{\prime} 07^{\prime \prime N}$ \\
\hline & Dec. 27,2008 & Mokpo Oebyeongdo & $125^{\circ} 56^{\prime} 47^{\prime \prime} \mathrm{E}$ & $34^{\circ} 22^{\prime} 12^{\prime \prime} \mathrm{N}$ \\
\hline & Dec. 27, 2008 & Mokpo Nurokdo & $125^{\circ} 57^{\prime} 34^{\prime \prime} \mathrm{E}$ & $34^{\circ} 20^{\prime} 52^{\prime \prime} \mathrm{N}$ \\
\hline
\end{tabular}


Distribution: Thalassiosira concaviuscula was originally described from the west coast of Africa (Makarova 1978). Lange et al. (1992) identified a species from the Danish Skagerrak, which they called Thalassiosira sp. 2. Following this, Harris et al. (1995) identified the species as $T$. concaviuscula and suggested that this species may have an extensive distribution in the northeastern Atlantic. Hoppenrath et al. (2007) isolated species from Helgoland and Sylt. In this study, and as Table 2 shows, T. concaviuscula was recorded from four different localities in Korean waters. This is also the first record of T. concaviuscula from Korea.

Remarks: Since it may have been previously misidentified as T. aestivalis, T. concaviuscula has rarely been recorded in literature. Makarova (1978) first described $T$. concaviuscula as a distinct species, but later recanted and reported it as a synonym for T. aestivalis Gran (Makarova 1988). However, it was found that T. concaviuscula differs from T. aestivalis in the position of the labiate process, which lies between the marginal strutted processes rather than replacing a strutted process as in T. aestivalis (Harris et al. 1995). Until now, differences between the 2 species, T. concaviuscula and T. aestivalis, were only observed in the position of the labiate process (Makarova
1978, Harris et al. 1995, Hoppenrath et al. 2007). New differential characteristics between these species were observed in this study. The valve mantle in T. concaviuscula forms a less sharp angle with the valve face than in T. aestivalis. Marginal ribs in T. concaviuscula are not well developed at the mantle edge, while they are continuations of the walls in T. aestivalis. Furthermore, the conspicuous central annulus and double layered external tube of the marginal strutted process are remarkable features of $T$. concaviuscula.

\section{Thalassiosira nanolineata (Mann) Fryxell and Hasle (PI. 2, figs 9-14)}

Hasle and Fryxell, 1977, p. 32, Figs 74-80; Hallegraeff 1984, p. 504, Figs 19a, b, c, d \& e; Licea 1990, p. 322, Figs 53-56; Sar et al. 2001, p. 213, Figs 37-40.

Basionym: Coscinodiscus nanolineatus Mann 1925, p. 68, Pl. 14, fig. 4, nec Coscinodiscus wittianus Pantocsek. Synonym: Coscinodiscus lineatus Ehrenb. In Schmidt 1878, Pl. 59, fig. 30; Van Heurck 1883, Pl. 131, fig. 3.

Cells are 10.1-14.9 $\mu \mathrm{m}$ in diameter. Valves have fine areolae arranged in straight parallel rows with 10-12 areolae on the valve face and 18-20 areolae on the valve

Table 2. Thalassiosira spp. morphological characters in the present study

\begin{tabular}{|c|c|c|c|c|c|c|c|}
\hline \multirow{2}{*}{ Species } & \multirow{2}{*}{ Diameter $(\mu \mathrm{m})$} & \multicolumn{2}{|c|}{$\begin{array}{l}\text { Areolae } \\
\text { in } 10 \mu \mathrm{m}\end{array}$} & \multicolumn{2}{|c|}{ Strutted process } & \multirow{2}{*}{ Labiate process } & \multirow{2}{*}{ Distinctive features } \\
\hline & & $\begin{array}{l}\text { Valve } \\
\text { face }\end{array}$ & $\begin{array}{c}\text { Valve } \\
\text { margin }\end{array}$ & $\begin{array}{l}\text { Valve } \\
\text { face }\end{array}$ & $\begin{array}{l}\text { Margin } \\
\text { in } 10 \mu \mathrm{m}\end{array}$ & & \\
\hline $\begin{array}{l}\text { Thalassiosira } \\
\text { concaviuscula }\end{array}$ & $6.4-20.4$ & $40-45$ & $40-45$ & $\begin{array}{c}\text { One } \\
\text { central }\end{array}$ & $4-8$ & $\begin{array}{l}\text { One lies between marginal } \\
\text { strutted processes }\end{array}$ & $\begin{array}{l}\text { Conspicuous central annulus, } \\
\text { double layered external } \\
\text { tubes of marginal strutted } \\
\text { processes }\end{array}$ \\
\hline T. nanolineata & $10.1-14.9$ & $10-12$ & $18-20$ & $1-2$ & $8-10$ & $\begin{array}{l}\text { One lies between marginal } \\
\text { strutted processes }\end{array}$ & $\begin{array}{l}\text { Various number of central } \\
\text { strutted processes, linear } \\
\text { areolation, double layered } \\
\text { external tubes of marginal } \\
\text { strutted processes }\end{array}$ \\
\hline T. oceanica & $5.4-7.8$ & - & - & $\begin{array}{c}\text { One } \\
\text { central }\end{array}$ & $3-5$ & $\begin{array}{l}\text { One lies between marginal } \\
\text { strutted processes }\end{array}$ & $\begin{array}{l}\text { Ridge structure between } \\
\text { marginal strutted processes }\end{array}$ \\
\hline T. partheneia & $7.3-8.0$ & $40-50$ & $40-50$ & $\begin{array}{c}\text { One } \\
\text { central }\end{array}$ & $3-5$ & $\begin{array}{l}\text { One lies between marginal } \\
\text { strutted processes }\end{array}$ & $\begin{array}{l}\text { Fairly convex valve face, } \\
\text { midway } \\
\text { position of labiate process } \\
\text { between marginal strutted } \\
\text { processes }\end{array}$ \\
\hline T. simonsenii & $27.7-35.5$ & $4-5$ & $7-8$ & $\begin{array}{c}\text { One } \\
\text { central }\end{array}$ & $5-6$ & $\begin{array}{l}\text { Two with large external } \\
\text { tubes at angle of } 130-150^{\circ}\end{array}$ & $\begin{array}{l}\text { Two labiate processes, } \\
\text { conspicuous marginal ribs, } \\
\text { linear areolation }\end{array}$ \\
\hline
\end{tabular}



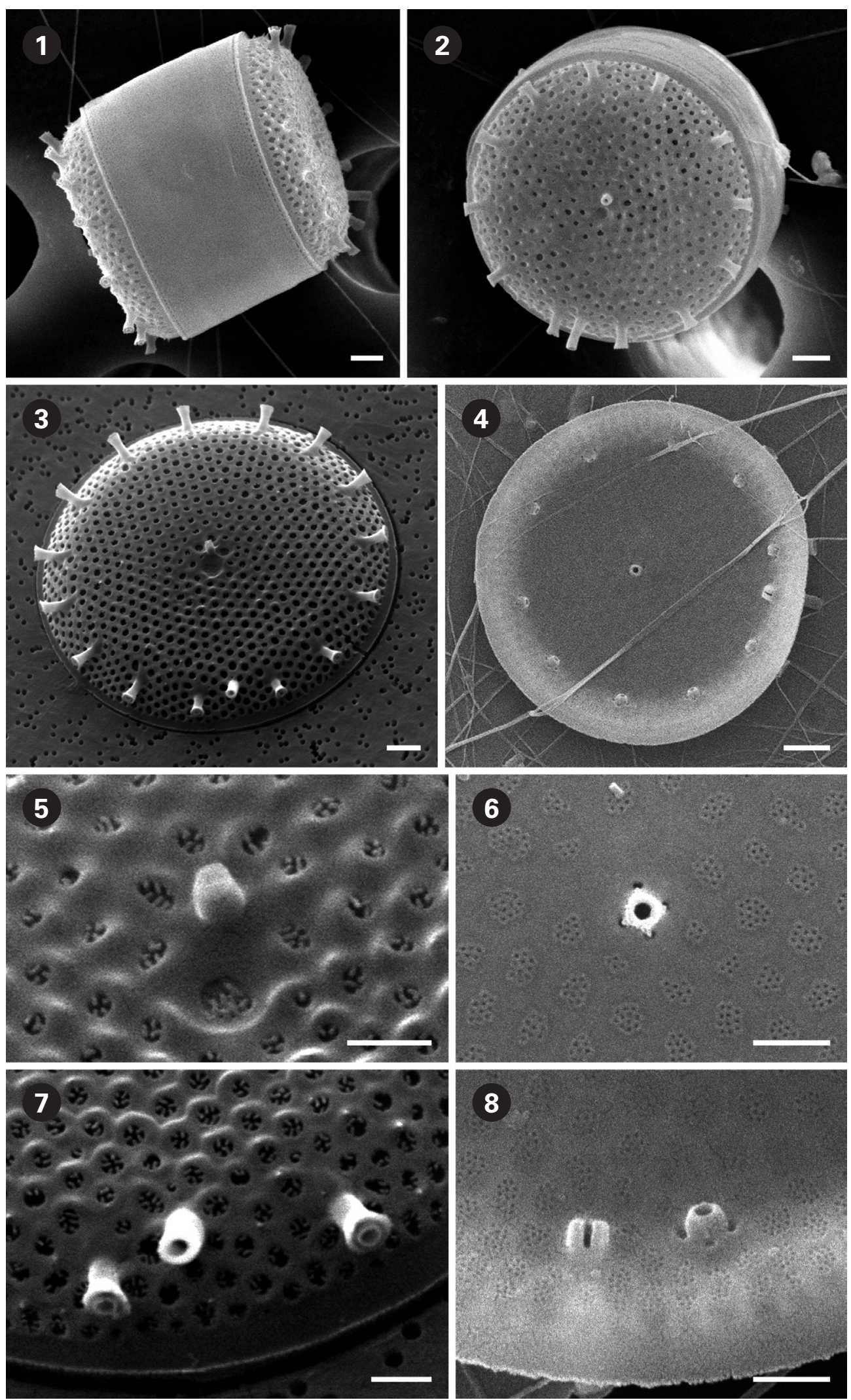

Plate 1. Thalassiosira concaviuscula. fig. 1. Girdle view. fig. 2. Valve view. fig. 3. Valve view slightly tilted. fig. 4. Internal valve view. fig. 5. External tube of central strutted process with annulus. fig. 6. Internal view of central strutted process with 4 satellite pores. fig. 7. External tube of marginal strutted and labiate process. fig. 8. Internal view of strutted and labiate process. Scale bars represent: figs 1-4, $7 \& 8,1 \mu \mathrm{m}$; figs 5 \& 6, $0.5 \mu \mathrm{m}$. 

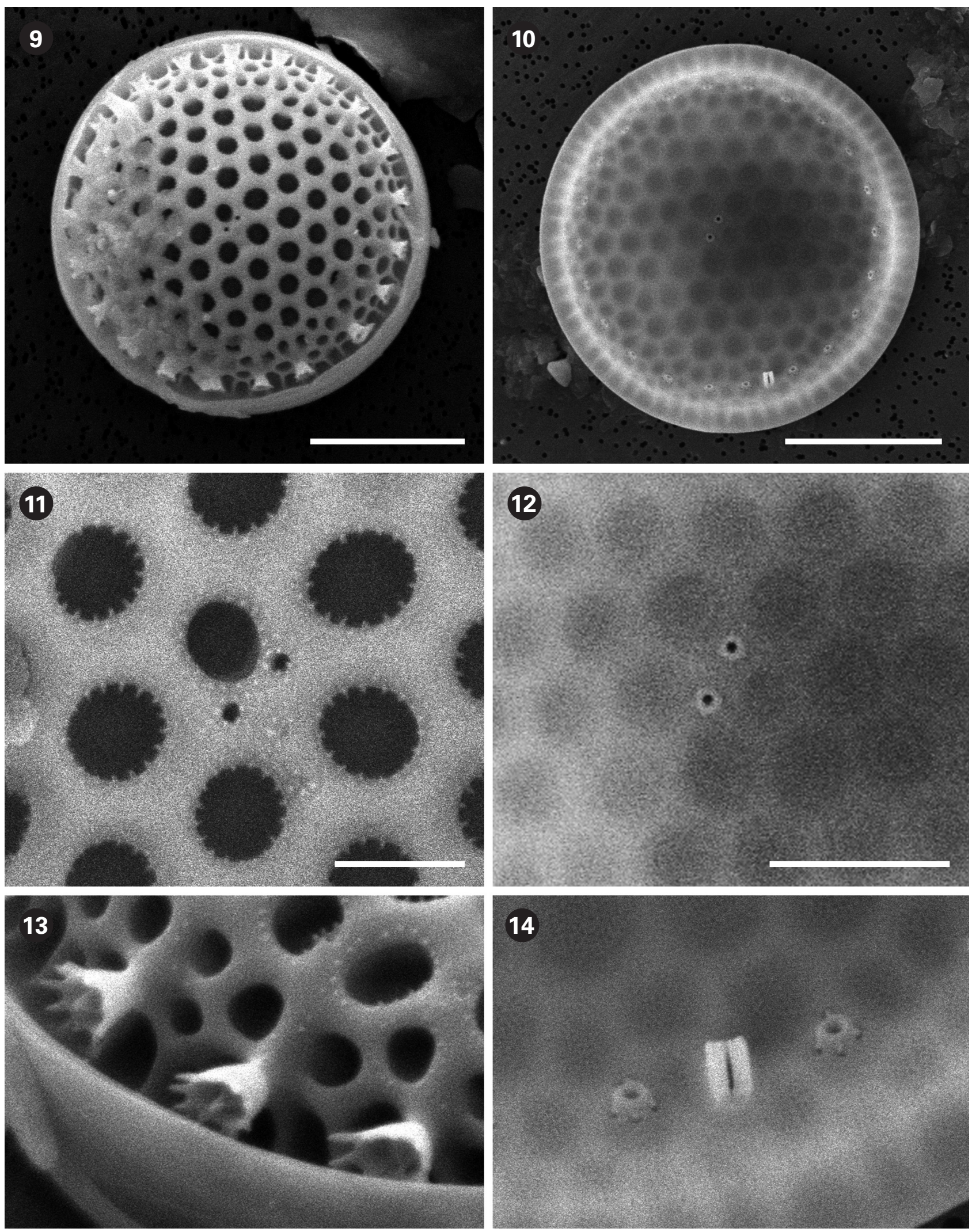

Plate 2. Thalassiosira nanolineata. fig. 9. External valve view. fig. 10. Internal valve view. fig. 11. External opening of 2 central strutted processes. fig. 12. Internal view of 2 strutted processes with 3 satellite pores. fig. 13. External tube of marginal strutted processes. fig. 14. Internal view of marginal strutted and labiate process. Scale bars represent: figs $9 \& 10,5 \mu \mathrm{m}$; figs $11-14,1 \mu \mathrm{m}$. 
mantle per $10 \mu \mathrm{m}$. One to two central strutted processes are adjacent to the wall of the central areola with one marginal ring of strutted processes with relatively short external tubes. There are 8-10 marginal processes per 10 $\mu \mathrm{m}$. One labiate process lies between two marginal strutted processes and is slightly further away from the edge of the valve mantle. Valves are slightly convex in the girdle view. In the external view, the central strutted processes are without a tube, while the marginal strutted processes have double layers as an external flared skirt. The labiate process is a simple tube without an external flared skirt. In the internal view, the central strutted processes have 3 satellite pores and the marginal strutted processes have 4 satellite pores. The labiate process is tangentially sessile. Distribution: Thalassiosira nanolineata is a warm water species that has been recorded from the Philippine Islands, the Gulf of Mexico, and Brazil (Hasle and Fryxell 1977), the Indian Ocean (Hallegraeff 1984), and the central part of the Bay of Campeche (Licea 1990). Sar et al. (2001) also found this species in Santa Teresita, La Lucila del Mar, Mar de Ajó, Pinamar and Villa Gesell, Argentina. In this study, T. nanolineata was first recorded in Korea at Mokpo.

Remarks: Hasle and Fryxell (1977) transferred C. nanolineatus to Thalassiosira due to the presence of the strutted processes and internal cribra. The distinctive features of T. nanolineata are linear areolation, various numbers of central strutted processes, and a double layered external tube on the marginal strutted processes.

\section{Thalassiosira oceanica Hasle (PI. 3, figs 15-22)}

Hasle 1983, p. 220, Figs 1-18; Hallegraeff 1984, p. 499, Figs 11a, b \& c; Herzig and Fryxell, 1986, p. 19, Figs 4 \& 5; Licea 1990, p. 315, Figs 15 \& 16; Harris et al. 1995, p. 121, Figs 8 \& 26; Hoppenrath et al. 2007, p. 80, Fig. 44.

Synonym: Cyclotella nana Guillard clone 13-1 in Guillard and Ryther 1962.

Cells are 5.4-7.8 $\mu \mathrm{m}$ in diameter. Valves have particularly fine ornamentation of radial ribs and poroid areolation covered by a finely perforated layer. One central strutted process is adjacent to a large areola and one marginal ring of strutted processes. There are three to five marginal processes in $10 \mu \mathrm{m}$. One labiate process lies beside one marginal strutted process. Valves are flat in the girdle view. In the external view, all strutted processes are without external tubes. The marginal ridge inter-links the marginal strutted processes. The labiate process is also without an external tube. In the internal view, one central strutted process has 3 satellite pores, and the marginal strutted processes has 4 satellite pores. The labiate process is tangentially sessile.

Distribution: Thalassiosira oceanica has previously been reported off the Chilean coast (Rivera 1981), California, the west coast of Africa, the Sargasso Sea, north-west America (Hasle 1983), Norway (Hasle 1983, Lange et al. 1992) and Australia (Hallegraeff 1984). It occurs mainly in warm waters, and is otherwise reported as cosmopolitan (Hoppenrath et al. 2007). This study recorded the first incidence of T. oceanica from the coast of Incheon in Korea. Remarks: As revealed by SEM, differential characteristics of T. oceanica are an undulating marginal ridge, spinules and sometimes a finely perforated top layer covering the radial ribs (Hasle 1983, Hallegraeff 1984).

\section{Thalassiosira partheneia Schrader (PI. 4, figs 23-28)}

Schrader 1972, p. 59, Pls 1 \& 2; Hasle 1983, p. 223, Figs 19 36; Fryxell et al. 1984, p. 143, Figs 2-16; Hallegraeff 1984, p. 497, Figs 6a, b, c \& d; Herzig and Fryxell, 1986, p. 19, Figs 30-33; Hoppenrath et al. 2007, p. 280, Fig. 47.

Cells are 7.3-8.0 $\mu \mathrm{m}$ in diameter. Valves have relatively coarse fasciculate areolation, and there are 40 to 50 per $10 \mu \mathrm{m}$. It has one central strutted process and one marginal ring of strutted processes. There are three to five per $10 \mu \mathrm{m}$. One labiate process lies midway between two marginal strutted processes. Valves are fairly convex in the girdle view. In the external view, all strutted processes are without external tubes. The labiate process is also without an external tube. The external opening of the strutted processes is circular while the labiate process is split toward the margin.

Distribution: Thalassiosira partheneia occurs mainly in warm waters (Hoppenrath et al. 2007). T. partheneia was first recorded from the Incheon coast in Korea.

Remarks: T. partheneia has shown variations in the degree of silicification (Schrader 1972, Hasle 1983, Fryxell et al. 1984). Schrader (1972) and Hasle (1983) reported lightly silicified species, whereas Fryxell et al. (1984) observed heavily silicified species. Our experiments showed only heavily silicified species. A fairly convex valve face and a midway position of the labiate process between two strutted processes are the distinctive features of $T$. partheneia.

\section{Thalassiosira simonsenii Hasle and Fryxell (PI. 5, figs 29-34)}

Hasle and Fryxell, 1977, p. 23, Figs 26-34 \& 97; Hallegraeff 1984, p. 507, Figs 22a, b, c \& d; Mahood et al. 1986, p. 130, 

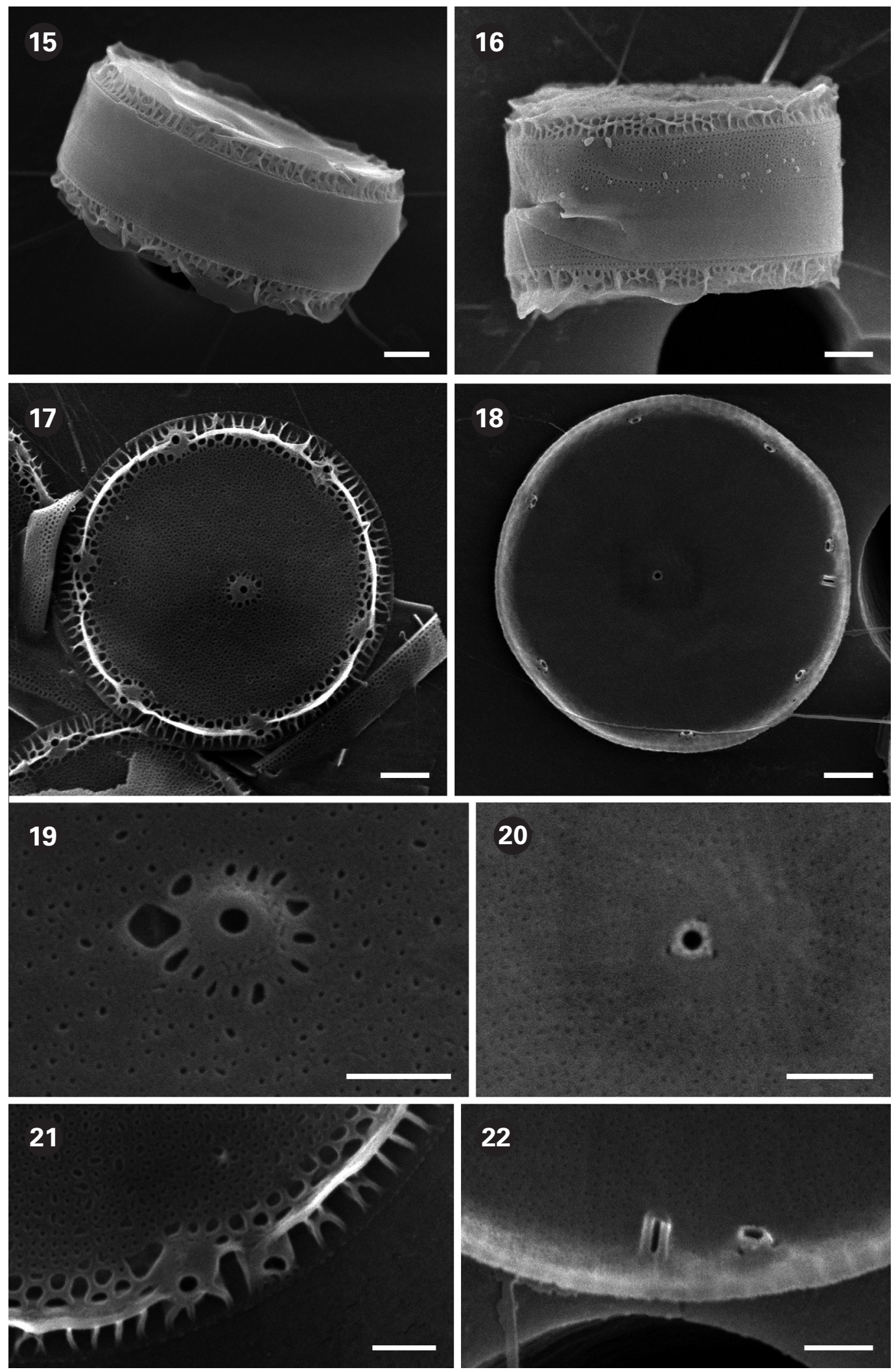

Plate 3. Thalassiosira oceanica. figs 15 \& 16. Girdle view. fig. 17. External valve view. fig. 18. Internal valve view. fig. 19. External opening of central strutted process. fig. 20. Internal view of central strutted process with 3 satellite pores. fig. 21. External opening of marginal strutted and labiate process with marginal ridge. fig. 22. Internal view of strutted and labiate process. Scale bars represent: figs 15-18, $1 \mu \mathrm{m}$; figs $19-22,0.5 \mu \mathrm{m}$. 

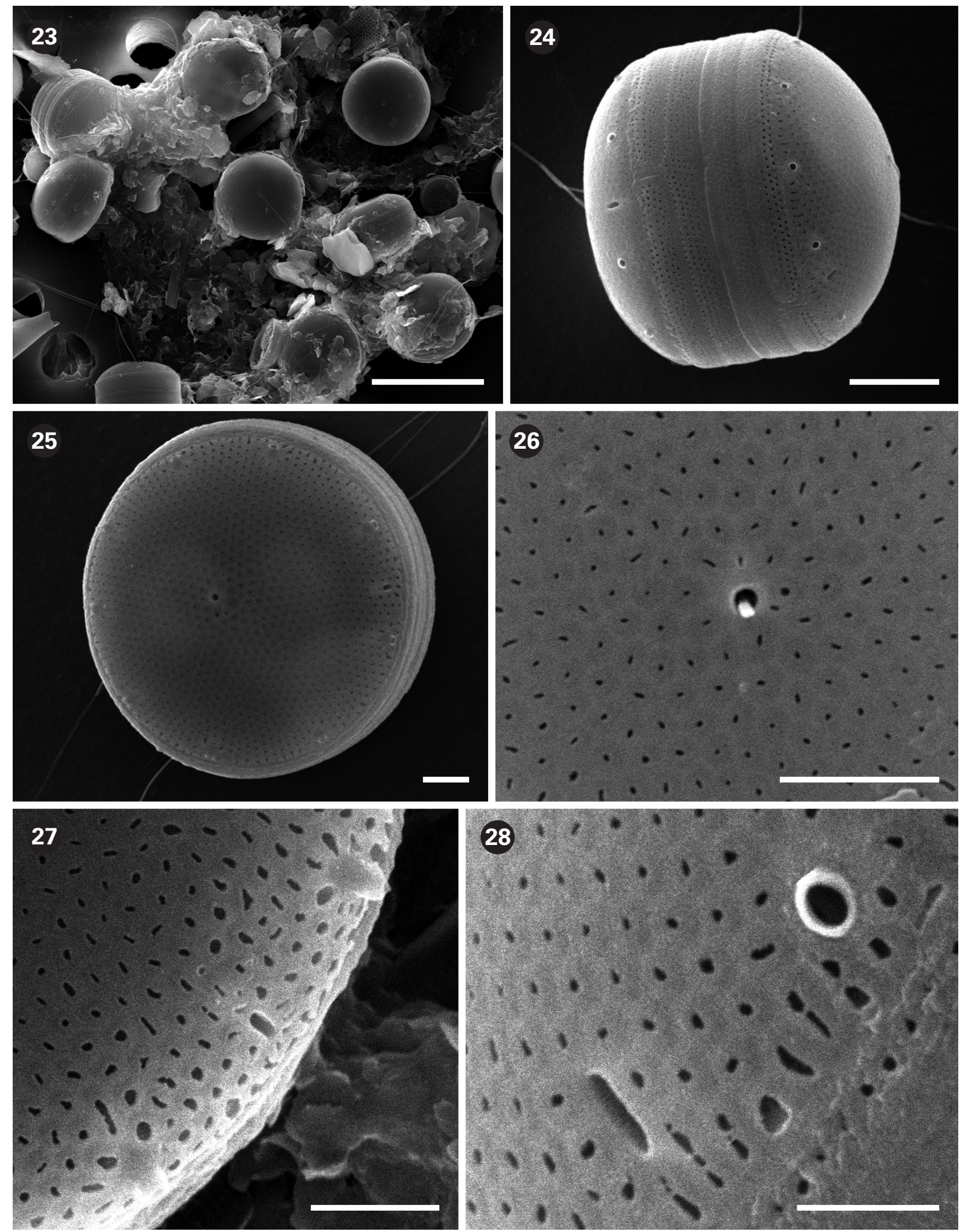

Plate 4. Thalassiosira partheneia. fig. 23. Mucilage colonies. fig. 24. Girdle view. fig. 25. External valve view. fig. 26. Central strutted process. fig. 27. External structure of marginal strutted and labiate process. fig. 28. External opening of marginal strutted and labiate process. Scale bars represent: fig. $23,10 \mu \mathrm{m}$; figs $24-28,1 \mu \mathrm{m}$. 

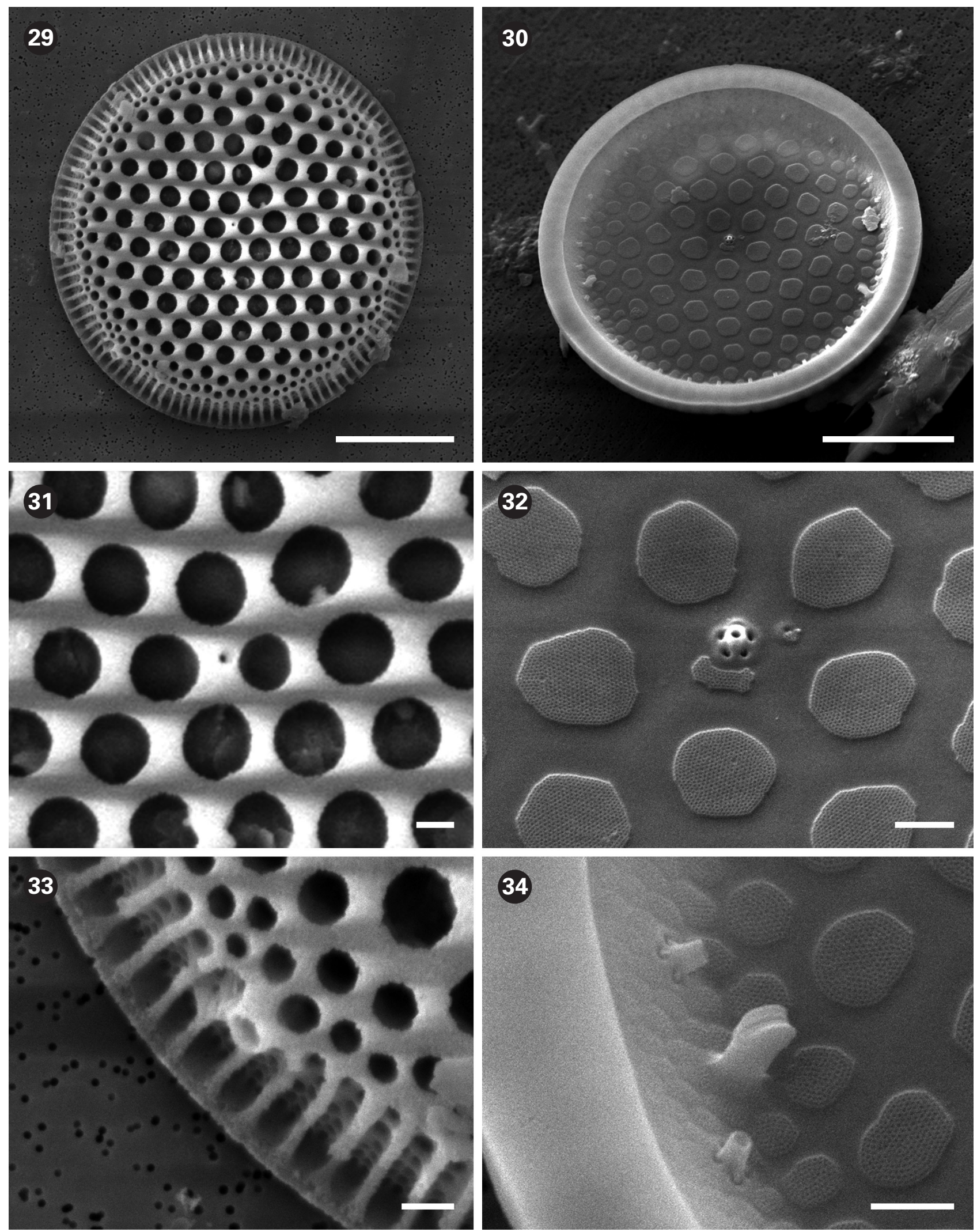

Plate 5. Thalassiosira simonsenii. fig. 29. External valve view. fig. 30. Internal valve view slightly tilted. fig. 31. External opening of central strutted process. fig. 32. Internal view of central strutted process with 5 satellite pores. fig. 33. External tube of labiate process. fig. 34. Internal view of marginal strutted and labiate process. Scale bars represent: figs $29 \& 30,10 \mu \mathrm{m}$; figs 31-34, $1 \mu \mathrm{m}$. 
Figs 2-5; Aké-Castillo et al. 1999, p. 495, Fig. 29; Sar et al. 2001, p. 216, Figs 54-56.

Cells are 27.7-35.5 $\mu \mathrm{m}$ in diameter. Valves have hexagonal areolae arranged in a linear pattern with 4-5 per $10 \mu \mathrm{m}$ across the valve and 7-8 at the mantle edge. One central strutted process is adjacent to a large areola and two alternating strutted processes on the margin with five to six per $10 \mu \mathrm{m}$. Two labiate processes with large external tubes are present at an angle between $130-150^{\circ}$ among the marginal strutted processes. Valves are flat in the girdle view. In the external view, one central strutted process is without a tube, while the marginal strutted processes have short tubes. The two labiate processes are more remarkable tubes than strutted processes. In the internal view, all strutted processes have 5 satellite pores. The labiate process is conspicuously stalked.

Distribution: T. simonsenii was recorded from the North Pacific Ocean (Hasle and Fryxell 1977) and San Francisco Bay (Mahood et al. 1986). This is the first record from Korean coastal waters.

Remarks: T. simonsenii has two labiate processes, which are situated $130-150^{\circ}$ apart. Other species that have two labiate processes are: T. elsayedii, T. hendeyi, T. fragilis, and T. symmetrica. However, the conspicuous marginal ribs of $T$. simonsenii provide the main differential characteristic for distinguishing this species from the ones mentioned above.

\section{CONCLUSIONS}

This study provides the first report of T. concaviuscula, T. nanolineata, T. oceanica, T. partheneia, and T. simonsenii in Korean waters, particularly from the coastal waters of Incheon, the north-west coast and the East Sea of Korea. Hence, the total number of Thalassiosira species for Korean waters is now thirty-six. Among these, only 25 Thalassiosira species have been described in detail by morphological studies using SEM (Lee and Yoo 1986, 1987, Lee and Park 2008, Park et al. 2009). Since fine structure, such as the strutted process patterns, cannot be observed by LM, other Thalassiosira species may have been previously misidentified. For a species diversity assessment of genus Thassiosira, regional investigations were carried out around the world: Argentina (Gayoso 1989, Sar et al. 2001, 2002), Australia (Hallegraeff 1984), German Bight of the North Sea (Hoppenrath et al. 2007), Britain (Belcher and Swale 1986), Netherlands (Muylaert and Sabbe 1996), Mexico (Hernández-Becerril and TapiaPeña 1995, Moreno et al. 1996, Aké-Castillo et al. 1999),
San Francisco Bay (Mahood et al. 1986), and Scotland (Harris et al. 1995).

The five Thalassiosira species studied here were smallsized. The form and position of the strutted processes and the number and position of labiate processes are the most striking features. These characteristics are difficult to recognize without SEM examination, but they are essential for the reliable identification of Thalassiosira species. Further highly detailed systematic studies are needed to confirm the presence of Thalassiosira species in Korean coastal waters reliably.

\section{ACKNOWLEDGEMENTS}

This work was supported by the National Research Foundation (NRF) Mid-Career Researcher Program grant funded by the MEST (Project No. 2009-0084603). The authors thank Dr. H.-U. Dahms (Sangmyung University, Korea) for English editing and critical comments on the manuscript. Thanks are also provided to all who in various ways helped with sample collection and technical assistance in this study, particularly S. W. Jung, H. M. Joo, S. M. Yoon and S. D. Lee in the Department of Green Life Science, Sangmyung University, Korea.

\section{REFERENCES}

Aké-Castillo, J. A., Hernández-Becerril, D. U. \& Meave del Castillo, M. E. 1999. Species of the genus Thalassiosira (Bacillariophyceae) from the Gulf of Tehauantepec, Mexico. Bot. Mar. 42:487-503.

Anonymous 1975. Proposals for a standardization of diatom terminology and diagnoses. Nova Hedwigia Beih. 53:323-354.

Belcher, J. H. \& Swale, E. M. F. 1986. Notes on some small Thalassiosira species (Bacillariophyceae) from the plankton of the lower Thames and other British estuaries (identified by transmission electron microscopy). Br. Phycol. J. 21:139-145.

Fryxell, G. A., Gould, R. W. Jr. \&Watkins, T. P. 1984. Gelatinous colonies of the diatom Thalassiosira in Gulf Stream warm core rings including T. fragilis, sp. nov. Br. Phycol. J. 19:141-156.

Fryxell, G. A., Hubbard, G. F. \& Villareal, T. A. 1981. The genus Thalassiosira: variations of the cingulum. Bacillaria 4:41-63.

Gayoso, A. M. 1989. Species of the diatom genus Thalassiosira from a coastal zone of the South Atlantic (Argen- 
tina). Bot. Mar. 32:331-337.

Hallegraeff, G. M. 1984. Species of the diatom genus Thalassiosira in Australian waters. Bot. Mar. 27:495-513.

Harris, A. S. D., Medlin, L. K., Lewis, J. \& Jones, K. J. 1995. Thalassiosira species (Bacillariophyceae) from a Scottish sea-loch. Eur. J. Phycol. 30:117-131.

Hasle, G. R. 1968. The valve processes of the centric diatom genus Thalassiosira. Nytt Mag. Bot. 15:193-201.

Hasle, G. R. 1978. Some Thalassiosira species with one central process (Bacillariophyceae). Nor. J. Bot. 25:77-110.

Hasle, G. R. 1983. The marine, planktonic diatoms Thalassiosira oceanica sp. nov. and T. partheneia. J. Phycol. 19:220-229.

Hasle, G. R. \& Fryxell, G. A. 1970. Diatoms: cleaning and mounting for light and electron microscopy. Trans. Am. Microsc. Soc. 89:469-474.

Hasle, G. R. \& Fryxell, G. A. 1977. The genus Thalassiosira: some species with a linear areola array. Nova Hedwigia Beih. 54:15-66.

Hasle, G. R. \& Syvertsen, E. E. 1996. Marine diatoms. In Tomas, C. R. (Ed.) Identifying Marine Diatoms and Dinoflagellates. Academic Press, San Diego, pp. 5-385.

Hernández-Becerril, D. U. \& Tapia-Peña, M. I. 1995. Planktonic diatoms from the Gulf of California and coasts off Baja California: species of the genus Thalassiosira. Bot. Mar. 38:543-555.

Herzig, W. N. \& Fryxell, G. A. 1986. The diatom genus Thalassiosira Cleve in Gulf Stream warm core rings: taxonomy, with T. intrannula and T. lineoides, spp. nov. Bot. Mar. 29:11-25.

Hoppenrath, M., Beszteri, B., Drebes, G., Halliger, H., van Beusekom, J. E. E., Janisch, S. \& Wiltshire, K. H. 2007. Thalassiosira species (Bacillariophyceae, Thalassiosirales) in the North Sea at Helgoland (German Bight) and Sylt (North Frisian Wadden Sea): a first approach to assessing diversity. Eur. J. Phycol. 42:271-288.

Lange, C. B., Hasle, G. R. \& Syvertsen, E. E. 1992. Seasonal cycle of diatoms in the Skagerrak, North Atlantic, with emphasis on the period 1980-1990. Sarsia 77:173-187.

Lee, J. H. \& Park, J. S. 2008. A study on the fine structure of the marine diatoms of Korean coastal waters: genus Thalassiosira 3. Algae 23:187-199.

Lee, J. H. \& Yoo, K. I. 1986. A study on the fine structure of the marine diatoms of Korean coastal waters: genus Thalassiosira 1. J. Oceanol. Soc. Korea 21:184-192.

Lee, J. H. \&Yoo, K. I. 1987. A study on the fine structure of the marine diatoms of Korean coastal waters: genus Thalassiosira 2. J. Oceanol. Soc. Korea 22:179-190.

Licea, S. 1990. Thalassiosira species from the Southern Gulf of Mexico. In Kociolek, J. P. (Ed.) Proc. 11th Int. Diatom Symp., California Academy of Sciences, San Francisco, pp. 311-335.

Mahood, A. D., Fryxell, G. A. \& McMillan, M. 1986. The diatom genus Thalassiosira: species from the San Francisco Bay system. Proc. Calif. Acad. Sci. 44:127-156.

Makarova, I. V. 1978. New data to the study of Thalassiosira Cl. (Bacillariophyta) from Atlantic Ocean. Bot. Zh. 63:222-224.

Makarova, I. V. 1988. Diatomovie vodorosli morei SSSR: rod Thalassiosira Cl. USSR Acad. Sci. Nauka, Leningrad, 116 pp.

Moreno, J. L., Licea, S. \& Santoyo, H. 1996. Diatomeas del Golfo de California. Autonomous University of Baja California Sur, SEP-FOMES, PROMARCO, La Paz, 273 pp.

Muylaert, K. \& Sabbe, K. 1996. The diatom genus Thalassiosira (Bacillariophyta) in the estuaries of the Schelde (Belgium/The Netherlands) and the Elbe (Germany). Bot. Mar. 39:103-115.

Park, J. S., Jung, S. W. \& Lee, J. H. 2009. A study on the fine structure of the marine diatoms of Korean coastal waters: genus Thalassiosira 4. Algae 24:67-77.

Rivera, R. P. 1981. Beiträge zur Taxonomie und Verbreitung der gattung Thalassiosira Cleve (Bacillariophyceae) in den Küstengewässern Chiles. Bibl. Phycol. 56:1-220.

Sar, E. A., Sunesen, I. \& Castaños, C. 2001. Marine diatoms from Buenos Aires coastal waters (República Argentina). I. Thalassiosiraceae. Nova Hedwigia 73:199-228.

Sar, E. A., Sunesen, I. \& Lavigne, A. S. 2002. The diatom genus Thalassiosira: species from the northern San Matías Gulf (Río Negro, Argentina). Nova Hedwigia 74:373-386.

Schrader, H. J. 1972. Thalassiosira partheneia, eine neue Gallertlager bildende zentrale Diatomee. Meteor Forsch. Ergeb. Reihe D 10:58-64.

Simonsen, R. 1979. The diatom system: ideas on phylogeny. Bacillaria 2:9-71. 